\title{
Politik pemberdayaan kelompok tani sawit swadaya di Kampung Sialang Palas, kecamatan Lubuk Dalam, Siak
}

\author{
Khairul Anwar*, \& Adianto \\ Universitas Riau \\ * khairul.anwar@lecturer.unri.ac.id
}

\begin{abstract}
Abstrak. Kegiatan pengabdian ini memiliki latar belakang konteks kampung Sialang Palas,Kecamatan Lubuk Dalam Kabupaten Siak. Wilayahnya ini terdiri $90 \%$ perkebunan sawit tetapi pola pemanfaatan lahan, teknologi informasi dan komunikasi, daya beli petani merosot, status gizi rumah tangga petani rendah. Sementara pengaruh kepemimpinan lokal semakin melemah, dan kelembagaan Gapoktan disfungsional. Dalam kondisi demikian terjadi perubahan perilaku politik petani semula kritis, dinamis,dan menjadi melemah, dihimpit struktur ruang berdemokarsi lokal semakin sempit, dan dampak perubahan ekonomi-politik nasional. Oleh karena itu, dibutuhkan peningkatan partisipasi petani dalam mengelola kelompok. Kegiatan ini bertujuan meningkatkan kapasitas petani sawit swadaya dalam mengelola kelompok tani dan membuat keputusan melalui aplikasi "sawitku: dan model pemberdayaan politik. Kegiatan ini dilaksanakan di Kampung Sialang Palas,Lubuk Dalam, Kabupaten Siak dan pengabdian ini mengambil tema "Pemberdayaan Masyarakat Era New-Normal". Masalahnya bagaimana meningkatkan kapasitas petani poktan dalam membuat keputusan dan mengelola kelompok di Sialang palas?Metode yang digunakan adalah: Pertama, persiapan dan sosialisasi program kepada kelompok tani Karya Bersama di kampung Sialang Palas.Kedua, melakukan ceramah dan diskusi materi (1) kepemimpinan; (2) manajemen kelompok; (3) proses pengambilan keputusan;(4) isu-isu strategis;(5) pengolahan potensi lokal (3) diskusi model "politik pemberdayaan" dan masalah-masalah pembangunan dan pemerintahan Lubuk Dalam;(6) Pendampingan dan Kampung Binaan. Hasil kegiatan pengabdian berupa: Pertama, artikel ilmiah yang dipublikasikan. Kedua,video kegiatan dan pengetahuan pembuatan keputusan kelompok. Ketiga, pengetahuan dan keterampilan mengolah limbah sawit dan pengetahuan gizi keluarga.
\end{abstract}

Kata Kunci: politik pemberdayaan, petani swadaya, modal sosial

\begin{abstract}
This service activity is set in the context of Sialang Palas Village, Lubuk Dalam District, Siak Regency. This area consists of $90 \%$ of oil palm plantations but land-use patterns, information and communication technology, decreased purchasing power of farmers, low nutritional status of farmer households. Meanwhile, the influence of local leadership is getting weaker, and Gapoktan institutions are not functioning. In this condition, there was a change in the political behavior of peasants which was initially critical, dynamic, and weakened, eroded by the narrower structure of the local democratic space, and the impact of changes in the national political economy. Therefore, farmer participation in group management needs to be increased. This activity aims to increase the capacity of independent smallholders in managing farmer groups and making decisions through the application of "my palm oil:" and a model of political empowerment. This activity was carried out in Sialang Palas Village, Lubuk Dalam, Siak Regency, and this service took the theme "Community Empowerment in the New-Normal Era". The problem is how to increase the capacity of poktan farmers in decision making and group management in Sialang Palas? The methods used are: First, preparation and socialization of the program to Karya Bersama farmer groups in Sialang Palas Village. Second, conducting lectures and discussing materials (1) leadership; (2) group management; (3) decision-making process; (4) strategic issues; (5) processing local potential (3) discussing the model of "empowerment politics" and issues of development and governance in Lubuk Dalam; (6) Village Assistance and Assistance. The results of the community service activities include: First, published scientific articles. Second, video activities and knowledge about group decision making. Third, knowledge and skills in processing palm oil waste and knowledge about family nutrition.
\end{abstract}

Keyword: political empowerment, independent farmer, social capital

To cite this article: Anwar, K. \& Adianto. 2020. Politik pemberdayaan kelompok tani sawit swadaya di Kampung Sialang Palas, kecamatan Lubuk Dalam, Siak. Unri Conference Series: Community Engagement 2: 409-415 https://doi.org/10.31258/unricsce.2.409-415

(C) 2020 Authors

Peer-review under responsibility of the organizing committee of Seminar Nasional Pemberdayaan Masyarakat 2020 


\section{PENDAHULUAN}

Kecamatan Lubuk Dalam adalah salah satu Kecamatan hasil pemekaran di wilayah Kabupaten Siak. Wilayah ini terdiri beberapa kampung diantaranya Sialang Palas. Kampung Sialang Palas dijadikan tempat pelaksanaan pengabdian kepada masyarakat karena wilayah ini memiliki potensi perkebunan kelapa sawit tetapi belum dikelola secara optimal. Hal ini Nampak dari fakta bahwa dijadikannya kampong ini sebagai sentra perkebunan sawit dan ternak sapi dan Balai penelitian pertanian.

Selain itu,Kecamatan ini memiliki 12 KELOMPOK Tani (Poktan) sawit swadaya yang tergabung dalam Gapoktan. Dilihat dari sisi nilai tukar petani, wilayah ini cenderung meningkat dan cenderung menurun pada masa pandemi covid-19. Sebagai gambaran NTP bulan Januari 2020, secara makro di Riau naik 7 kali NTP nasional. (hanya naik 0,78\%). NTP Riau Desember 2019 117,37 meningkat 123,93 (5,59 \%). Selain itu, berdasarkan Peraturan Daerah (Perda) Nomor 13 tahun 2001, Pemda Riau mencadangkan lahan perkebunan seluas 3.1333.198 Ha (Anwar, 2009). Namun, masalahnya adalah berbagai potensi SDA tersebut belum dimanfaatkan secara optimal dan organisasi petani Gapoktan dan Poktan belum berfungsi sebagai sekolah bagi petani. Secara faktual, kondisi ini penting dicarikan solusinya, guna memperkuat jaminan sosial era Covid-19.

Di Kampung Sialang Palas- Lubuk Dalam terdapat 610 orang petani sawit swadaya yang tersebar kepada 12 poktan. .Dilihat dari usia petani sawit terbanyak berkisar 15 tahun -55 tahun (82\%), dan usia 35 tahun sebanyak 35 orang ( $6 \%$ ), 35-45 tahun 72 orang (12\%) Sebagai perbandingan, secara makro usia penduduk kecamatan dan kabupaten Siak 54\% 15-44 tahun (Disdukcapil,Siak,2019). Masing POKTAN terdiri dari 8-16 petani dan $90 \%$ anggota GAPOKTAN tidak mempunyai Visi kelompok..Tingkat pendidikan petani sawit GAPOKTAN tidak tamat $\mathrm{SD}=57$ orang ( 9\%), Tamat $\mathrm{SD}=225$ orang $(37 \%)$, SLTP=168 orang (28\%), SLTA $=145$ orang $(24 \%)$ dan Diploma $=15$ orang $(2 \%)$. Petani laki-laki $=427$ Orang $(70 \%)$ dan perempuan $=$ 183 orang (30\%). Di samping Poktan dan Gapoktan terdapat kelompok sosial lainnya misalnya Karang Taruna, KNPI dan sebagainya tetapi kondisinya lumpuh layu.

Fakta di atas menunjukkan bahwa terjadi perubahan sosial ekonomi RumahTangg a petani ditengah-tengah melemahnya fungsi organisasi sosial kemasyarakatan. Kesenjangan berorganisasi dan menurunnya produktivitas petani adalah masalah besar yang harus dicarikan solusinya. Sehingga dibutuhkan tindakan pemberdayaan petani terutama dalam akses pengambilan keputusan di tingkat lokal. Berbagai isu strategis ini memunculkan tantangan perlunya pemberdayaan organisasi Gapoktan sawit swadaya sebagai basis kehidupan sosial ekonomi dan kesehatan masyarakat kampung. Gagasan ini jawaban ditengah-tengah melemahnya organisasi-organisasi sosial misalnya karang taruna, organisasi pemuda, Badan Permusyawaratan Kampung (BAPEKAM). Berdasarkan identifikasi makro situasi yang telah disampaikan pada bagian awal rancangan kegiatan ini, permasalahan yang akan dicarikan solusinya adalah sebagai berikut: potensi lokal belum dimanfaatkan optimal, sementara organisasi Poktan membutuhkan pemberdayaan pengetahuan,keterampilan,peningkatan ekonomi keluarga dan kesehatan terutama era new-normal. Dari masalah pokok ini dapat dirumuskan beberapa pertanyaan yang menuntun kegiatan pengabdian: (1) Apa saja masalah Poktan dalam proses pengambilan keputusan di kampung Sialang Palas? (2) Bagaimana manajemen Poktan dalam memanfaatkan potensi limbah sawit dan ternak?

Kegiatan pengabdian kepada masyarakat ini bertujuan adalah sebagai berikut: (1) meningkatkan kapasitas para petani sawit swadaya dalam mengelola Gapoktan melalui sistem aplikasi "sawitku"; (2) meningkatkan kapasitas pengetahuan dan keterampilan anggota Poktan dalam membuat keputusan kelompok melalui model "politik pemberdayaan petani" (2) Meningkatkan ekonomi rumah tangga petani melalui pemanfaatan potensi SDA limbah sawit sebagai alternatif unggulan kampung dalam rangka meningkatkan daya saing petani .

Ada dua perspektif yang menjadi inspirasi pengabdian politik pemberdayaan petani ini, yaitu konseptualisasi yang diketengahkan Barrington Moore, dan cara pandang G.Therbon dalam Mas'oed,2005. Pertama, perspektif hubungan kapital dan Kelembagaan demokrasi menurut Moore, adalah bahwa proses demokratisasi suatu bangsa sangat dipengaruhi oleh pola hubungan antara kelas priyayi pemilik tanah,petani,dan borjuasi kota dengan negara pada masa berlangsungnya proses modernisasi. Dalam sejarahnya,masing-masing negara menempuh jalan yang berbeda-beda. Berbeda dengan para teoritisi modernisasi lainnya,yaitu memandang demokrasi sebagai satu-satunya akhir dari perjalanan modernisasi masyarakat. Moore berpandangan ada jalu-jalur alternatif transformasi sosial-ekonomi.

Kedua, perspektif demokratisasi Therbon,dalam Potter dalam Mas'oed (2005) memandang ada peran kapital dalam pelembagaan demokrasi, yaitu: (1) Kapitalisme menciptakan pasar tenaga kerja "bebas", artinya,buruh,yang dibebaskan dari tuan tanah, bisa menjual atau membeli tenaga kerja demi upah; (2) Kapitalisme memberi landasan yang kemudian dipakai oleh buruh untuk memperjuangkan nasipnya. Gerakan 
buruh ini memberikan peran pokok dalam memperjuangkan demokrasi. Selain itu, hubungan produksi kapitalis cenderung menciptakan kelas penguasa yang secara internal saling berkompetisi dan terpecah belah dalam beberapa fraksi, seperti pedagang, bank, industri, pertanian, perkebunan dan sebagainya. Dalam kondisi demikian, muncul lembaga-lembaga legislatif demokrasi parlementer melalui tuntutan kelas-kelas domina memerlukan mekanisme politik yang memungkinkan proses pemilihan, musyawarah dan perwakilan berlangsung. Selanjutnya Moore,dalam Mas'oed (2003) memandang ada tiga faktor yang menentukan kapan suatu negara kapitalis bergerak menuju demokrasi: (a) faktor pengalaman dalam dalam perang. Suatu negara kalah dalam perang dan kemudian memaksakan pelaksanaan demokrasi,misalnya Austria,jerman dan Jepang. (b) Faktor mobilisasi rakyat menghadapi ancaman dari luar. Prose ini mencakup aspek demokratisasi sebagai sarana melakukan mobilisasi nasional untuk keperluan perang; aspek demokratisasi sebagai akibat dari mobilisasi rakyat dalam masa perang. (c) faktor murni perkembangan internal, misalnya perpecahan di kalangan kelas-kelas penguasa. Cara pandang yang mementingkan struktur sosial dalam proses demokratisasi di atas, diperkuat oleh Richard Robison dalam studi demokratisasi di negara-negara Industri baru (NIB) di Asia Timur dan Asia Tenggara yang menemukan ada ciri-ciri pengalaman pelembagaan demokrasi yang sama.

\section{METODE PENERAPAN}

Dalam rangka mencapai tujuan kegiatan pengabdian kepada masyarakat ini, metode yang dipakai adalah: Pertama, ceramah dan diskusi. Adapun materi kegiatan ceramah dan diskusi ini bertujuan memberikan inspirasi adanya ruang dialog antar berbagai kelompok dan struktur aturan publik yang harus diikuti. Kegiatan ini menjelaskan contoh-contoh isu-isu strategis pembangunan; pentingnya memahami masalah kesehatan, ekonomi dan bagaimana keputusan dibuat.kan dengan memanfaatkan Isu-isu pembangunan pedesaan melalui aplikasi "sawitku" kedalam metode pengumpulan data (wawancara, dan kuesioner, observasi, dokumentasi). Ceramah dan diskusi dilakukan menggunakan alat bantu zoom meeting, slide, infocus, komputer dan alat-alat tulis (ATK).

Kedua, Simulasi (daring) modul kegiatan memanfaatkan limbah kelapa sawit dan materi umum gizi keluarga. Metode ini dilakukan dengan cara mendemonstrasikan praktik mengolah limbah sawit menjadi kerajinan, piring dan tikar. Kegiatan ini melibatkan mahasiswa.Secara umum kegiatan ini membagi khalayak sasaran kedalam dua kelompok. Masing-masing kelompok akan disampaikan ilustrasi kasus contoh manajemen kelompok dan proses pengambilan keputusan dan pemanfaatan limbah sawit dan ternak, masing kelompok akan menentukan bentuk dan jenis produk limbah, metode yang digunakan dalam mengolah limbah dan membuat kesimpulan.

Ketiga, evaluasi. Setelah kegiatan pengabdian berjalan,dilakukan evaluasi dengan tujuan ingin mengetahui dan menganalisis permasalahan yang muncul antara upaya pencapaian tujuan yang sudah dirumuskan dan kenyataan praktik kegiatan yang berlangsung.Kesenjangan yang dijumpai akan menjadi permasalahan kegiatan pengabdian masyarakat yang akan dicari pemecahannya pada tahun berikutnya.

Indikator keberhasilan kegiatan pengabdian kepada masyarakat ini bertumpu kepada;(1) kehadiran khalayak sasaran dalam setiap tahapan kegiatan;(2) jumlah khalayak sasaran yang menginginkan kembali kegiatan ini kembali dilaksanakan; (3) pengetahuan dan keterampilan dalam membuat keputusan, pengetahuan umum kesehatan dan memanfaatkan limbah sawit.

\section{HASIL DAN KETERCAPAIAN SASARAN}

\section{Pelaksanaan diskusi}

Kegiatan dimulai dengan wawancara offline dengan Ade Hartono sekretaris Gapoktan Karya Bersama. Kegiatan ceramah dan Tanya jawab di Sekretariat dan kandang Ternak Sapi Kelompok Tani Karya Bersama. Adapun materi ceramah dan diskusi adalah sebagai berikut:

Materi I: sosialisasi program kepada kelompok tani di Kampung Sialang palas. Materi II: Peningkatan kapasitas kepemimpinan kelompok dan bagaimana petani membuat keputusan? Materi III: Pengetahuan dan praktik menerapkan manajemen kelompok. Materi IV: Analisis isu-isu strategis pembangunan perdesaan. Materi V: Pengelolaan dan Pemanfaatan potensi lokal. Setelah itu, dilakukan Tanya jawab. Materi VI: penjelasan kaitan model dengan masalah-masalah pembangunan dan pemerintahan Kecamatan Lubuk Dalam. Bagaimana metodenya? Apa saja yang dilakukan? Bagaimana menggunakan alat-alat peraga model? Materi VII. Teknik dan Materi pendampingan Poktan di Kampung Sialang Palas.

Kegiatan ceramah dimulai setelah disampaikan pengantar diskusi oleh ketua Poktan Karya Bersama Kampung Sialang Palas Kecamatan Lubuk Dalam Kabupaten Siak. Dalam kata pengantarnya, Ketua Poktan 
berharap acara kegiatan pengabdian ini dapat memberikan manfaat kepada pengurus dan anggota Poktan dan Gapoktan kampung yang hadir dan dapat diaplikasikan dalam meningkatkan pengetahuan dan keterampilan.Kegiatan ceramah dan diskusi ini diikuti oleh 28 orang peserta yang terdiri dari 13 orang dari Ketua Poktan dan 15 pengurus Poktan dihadiri oleh anggota Poktan Sialang Palas, Tim Kegiatan Pengabdian dan Mahasiswa

Ceramah dan diskusi Materi I. (a) Isu-Isu dan masalah strategis Pembangunan Kampung adalah wilayah ini memiliki luas sekitar 1.660 Ha terdiri dari dua Dusun, 4 Rukun Warga (RW) dan 15 Rukun tetangga (RT). Wilayah kampong ini terdiri dari daratan dengan kondisi geografis berbukit-bukit.Kampung Sialang Palas merupakan wilayah sebagian penduduknya bermata pencaharian dari sektor pertanian dan perkebunan kelapa sawit di samping sektor peternakan dan sektor perikanan darat dan perdagangan. Secara demografis, Kampung Sialang Palas memiliki jumlah penduduk 2.074jiwa, yang terdiri dari laki-laki 1.062 jiwa, perempuan 1.012 jiwa dan 600 Kepala Keluarga (KK).

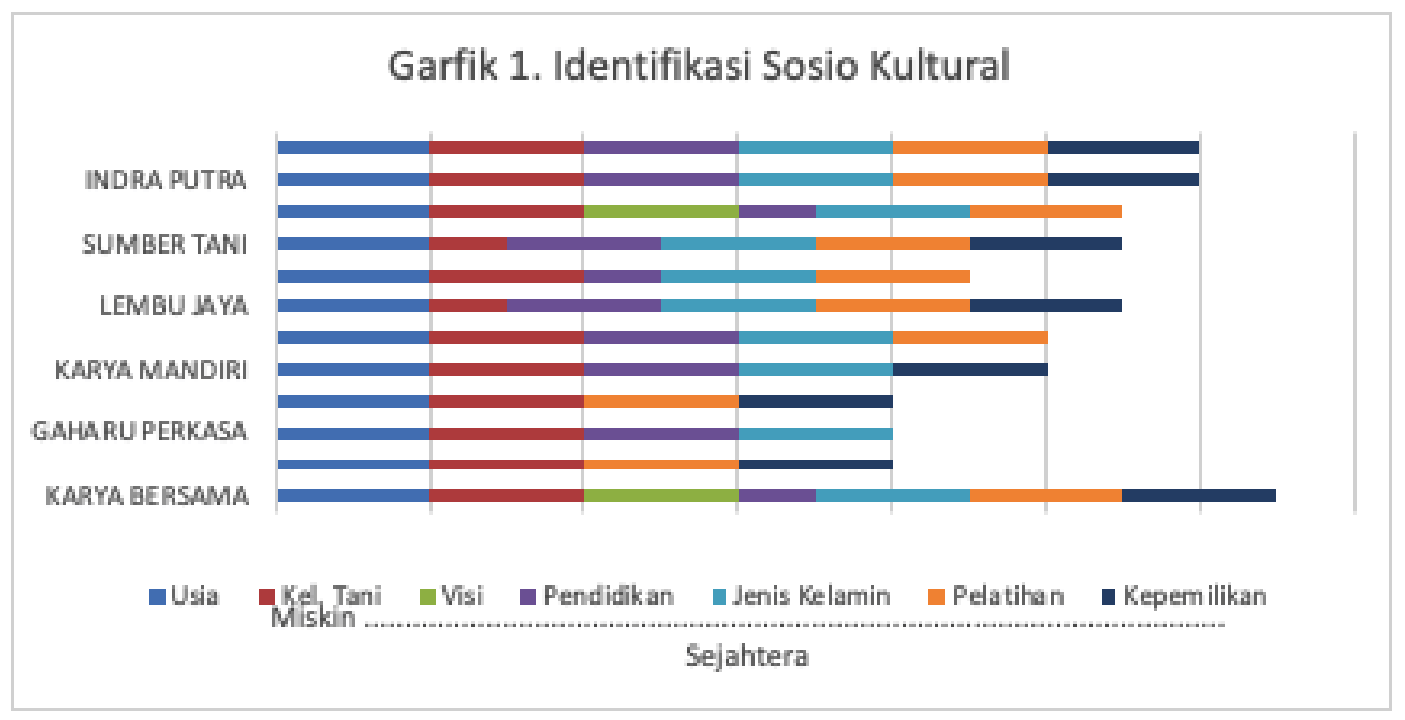

Gambar 1. Grafik Identifikasi Sosio Kultural

Materi I. (b) Isu dan masalah SDM Petani: Tingkat pendidikan masyarakat kampung Sialang Baru sebagian besar tamat SD/sederajat (757 0rang), tidak tamat SD/Sederajat (480 orang), SLTP/Sederajat (355 orang), tamat D1 (8 orang), Tamat D3 (12 orang), dan S1 (22 orang) (Monografi Sialang Palas, 2015).

Materi I. (c) Isu Strategis sumber daya alam terbesar yaitu perkebunan kelapa sawit (1.132,5 ha), dan pasir (3000 kubik). Sumberdaya sosial dan budaya misalnya kelompok-kelompok sosial keagamaan (majelis taklim,wirid yasin, lembaga adat, tokoh adat, rebana, kelompok kuda lumping). Potensi sosial berupa organisasi sosial kemasyarakatan misalnya Karang Taruna, Remaja Masjid, Organisasi PKK, AMPI, KNPI, Kelompok Tani dan sebagainya. Masalahnya kelembagan petani dan organisasi sosial semakin melemah secara fungsional. Tabel 2 menjelaskan data analisis basis sosial/institusional dan jaringan petani POKTAN Sawit di Kecamatan Lubuk Dalam-Riau. Menurut informan umumnya senang bergabung ke dalam POKTAN (80\%) dengan alasan dapat bertukar pikiran,mendapat informasi harga TBS dapat berjumpa. Namun dua informan yang menyatakan tidak senang dan kadang-kadang tidak percaya (20\%) dengan alasan POKTAN hingga saat ini tidak ada kelanjutan kegiatan.

\section{Solusi Masalah}

Solusi yang ditawarkan dalam mengatasi masalah pemberdayaan Poktan Kampung Sialang Palas adalah melakukan Pemberdayaan Organisasi Poktan dan Gapoktan, pengurus beserta anggotanya. melalui rejuvenasi modal sosial dengan kegiatan ceramah dan pelatihan daring. Kegiatan peremajaan modal sosial ini terdiri dari penjelasan dari contoh-contoh pengelolaan manajemen Poktan dan Gapoktan serta pemanfaatan potensi limbah sawit dan ternak. Misalnya dalam membuat keputusan kelompok terkait pasar input,pasar output, dan pasar konsumsi.Selain itu, disampaikan juga metode pengolahan limbah sawit. isu strategis pasar konsumsi petani misalnya usaha pemenuhan kebutuhan bahan-bahan konsumsi petani sehari-hari misalnya beras,kopi,gula, minyak goreng, air bersih dan sebagainya. Berbagai isu strategis ini didiskusikan dan dipraktekkan melalui model open governance menjelaskan manfaat model dalam metode pengumpulan data 
misalnya wawancara, observasi, dokumentasi, FGD. Ceramah dan diskusi dilakukan menggunakan alat bantu slide, infocus, computer, camera dan alat-alat tulis (ATK).

Selanjutnya menjelaskan model konseptual Politik Pemberdayaan Petani Gambar.1 untuk mempertajam kegiatan diskusi dilakukanlah metode simulasi menjaring aspirasi masyarakat kampung. Tabel 2 menginformasikan modal sosial POKTAN sawit. Modal ini dipercaya dapat meredam konflik sosial dan menciptakan kedamaian (98\%) karena POKTAN dibangun atas dasar saling percaya. Ada informan yang tidak percaya (2\%) POKTAN meredam konflik dengan alasan tergantung konflik yang terjadi. Dalam pergaulan sehari-hari, POKTAN dilandasi kebersamaan, saling percaya,tidak diskriminasi (98\%). Namun ada informan berpendapat kadang-kadang tidak percaya diri (2\%). Seluruh informan,percaya kerjasama di POKTAN berjalan tanpa rasa saling curiga (100\%). Karena itu itu, POKTAN dipercaya dapat menyelesaikan masalah sehari-hari (100\%). Karena alasan mendapatkan informasi. Gabungan kelompok tani ini juga menjadi sarana artikulasi kepentingan dan aspirasi petani (100\%), karena alasan keputusan dilakukannya musyawarah. Sehingga menurut informan kebersamaan menjadi nilai utama dalam interaksi anggota,karena ikatan kekerabatan satu kampung tempat tinggal,daerah asal, tetangga dan keluarga (100\%).

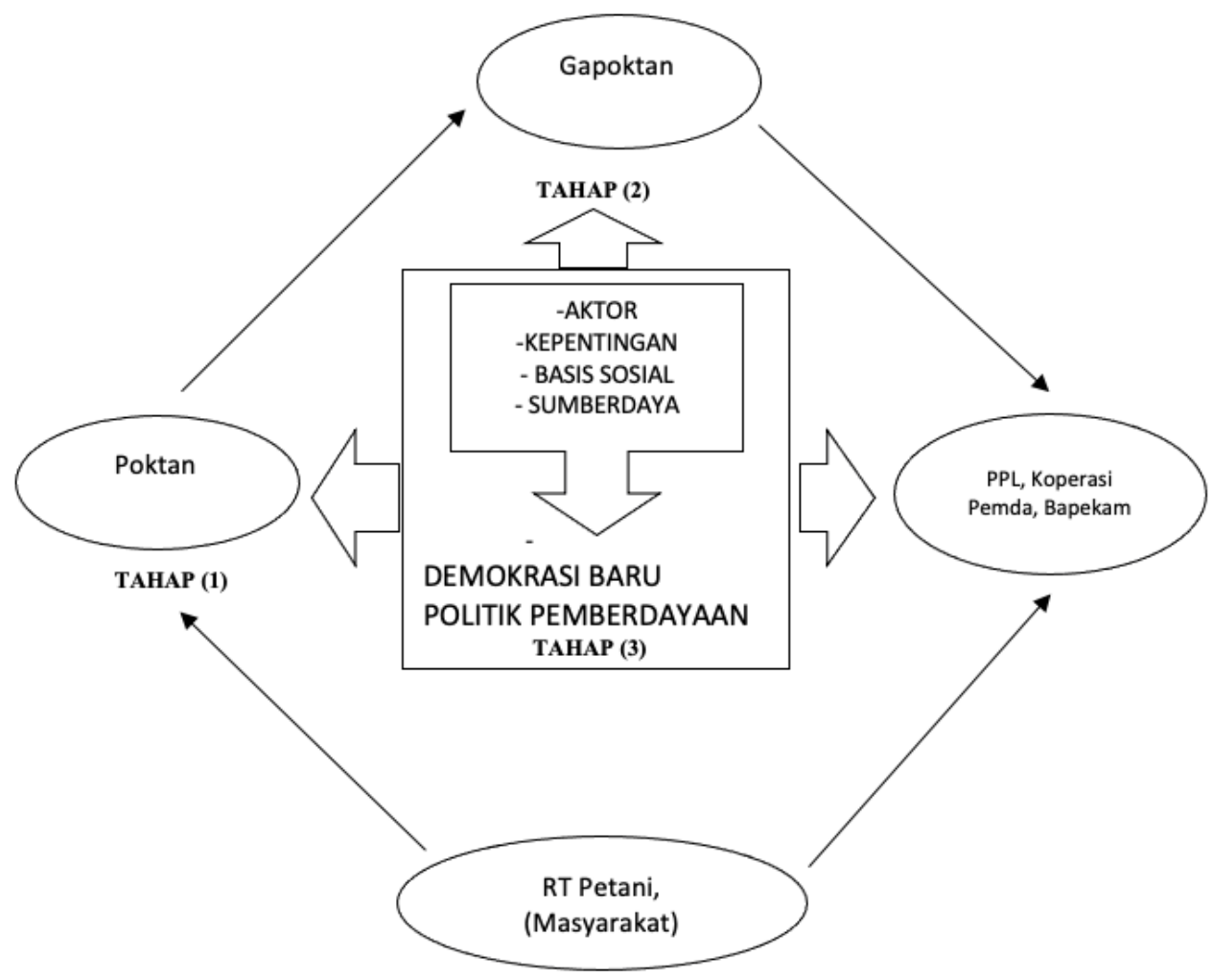

Gambar 2. Model Konseptual Politik Pemberdayaan POKTAN dan GAPOKTAN (Sumber: Anwar, 2019)

Model ini mengetengahkan empat variabel ekonomi-politik utama yang seringkali menimbulkan ketegangan sosial-politik variabel tersebut adalah: (1) aktor pelaku, mengidentifikasi pola dan arah interaksi aktor-aktor pelaku organisasi Poktan dan Gapoktan yang "mendukung" atau yang "menolak" dalam wacana pemanfaatan limbah perkebunan kelapa sawit di Sialang Palas, dan menentukan apa yang menjadi tujuan dan kepentingannya. Langkah ini mengasumsikan para aktor pelaku adalah individu yang berupaya memaksimalkan utilitas, dan melakukan perhitungan keuntungan dan kerugian sebaik-baiknya dalam mencapai tujuan. Selain itu akan dianalisis juga perilaku aktor dari kalangan Perusahaan pengembang kebun sawit. (2), menggambarkan proses preferensi masing-masing pelaku organisasi Poktan dan Gapoktan mengenai kegiatan pemanfaatan SDA limbah perkebunan kelapa sawit yang akan diterapkan di Kampung Sialang Palas. Sebagaimana diketahui bahwa terdapat setidaknya tiga tingkatan keanggotaan Poktan yaitu, pengurus, anggota dan simpatisan. Dari tiga tingkatan anggota Poktan tersebut dalam pelaksanaannya terdapat paling tidak empat isu utama yang terkait dengan kebijakan perkebunan, yaitu; pertanahan, lapangan kerja, teknologi, dan ketersedian limbah. Dalam mengatasi masalah itu para aktor digambarkan sebagai pihak yang 
suka pada pola yang dapat memaksimalkan keuntungannya. (3), mendeskripsikan bagaimana para aktor pelaku organisasi berkoalisi dalam mencapai tujuan yang ditetapkan. Koalisi ini dilakukan dalam rangka memperkuat daya tawar terhadap pihak lain. Para aktor mengkompromikan kepentingannya dengan aktor atau kelompok lainnya. Langkah ini antara lain bertujuan untuk mendapatkan dukungan dalam memperkuat koalisi. Dalam kasus pemanfaatan limbah sawit dan ternak di Sialang Palas. Kelompok yang "mendukung" pemanfaatan limbah sawit dan ternak baik yang berasal dari kalangan pemerintah Daerah maupun Poktan dan Gapoktan melakukan konsolidasi. Tujuannya agar dapat meyakinkan pihak yang menolak "rejeki" pembangunan kelapa sawit pada akhirnya dapat menerima. (4), menganalisis faktor-faktor yang mempengaruhi para aktor berinteraksi dengan lembaga-lembaga sosial lainnya dalam rangka memperjuangkan kepentingan untuk mencapai tujuan. Apakah memakai pendekatan "bargaining", "persuasi", atau "komando", Aktor yang responnya "mendukung" pembangunan perkebunan kelapa sawit baik dari Pemerintah Daerah maupun Swasta mempunyai sumber daya ekonomi-politik besar berkemungkinan melakukan tawar menawar atau "tekanan" kepada aktor atau kelompok yang responnya "menolak" kebijakan atau "hasil" perkebunan kelapa sawit yang diperoleh masyarakat Riau.

Materi IV: Pelatihan memanfaat limbah sawit. Penyuluhan dan latihan ini dilakukan tim kegiatan pengabdian bersama mahasiswa. Pemanfaatan limbah sawit dan ternak dalam buku ini dengan mengambil contoh kampung di Kabupaten Siak yaitu, Kampung Sialang Palas. Kampung ini merupakan salah satu Kampung di Kecamatan Lubuk Dalam, Kabupaten Siak, Provinsi Riau.Kampung ini memiliki luas wilayah 1.660 Ha yang sebagian besar dimanfaatkan untuk usaha perkebunan kelapa sawit.

Materi V: mendiskusikan materi I, II, III, dan IV dalam bentuk tanya jawab antara pelaku kegiatan pengabdian dengan peserta dan antara peserta dengan peserta lainnya. Tanya jawab ini lebih banyak mengetengahkan sisi pengalaman masing-masing peserta dan bagaimana menggunakan model dalam penerapan kegiatan pemerintahan sehari-hari.

Beberapa contoh pertanyaan dan jawaban dalam diskusi sebagai berikut:

1) Apa "politik pemberdayaan" itu?

2) Bagaimana caranya mengolah limbah sawit dan ternak?

3) Apa yang dimaksud dengan modal sosial dan asinergi?

4) Bagaimana mengelola dinamika kelompok?

Dalam mengakhiri kegiatan pengabdian ini dilakukan evaluasi. Setelah kegiatan pengabdian berjalan, dilakukan evaluasi dengan tujuan ingin mengetahui dan menganalisis permasalahan yang muncul antara upaya pencapaian tujuan yang sudah dirumuskan dan kenyataan praktik kegiatan yang berlangsung. Kesenjangan yang dijumpai akan menjadi permasalahan kegiatan pengabdian masyarakat yang akan dicari pemecahannya pada tahun berikutnya. Indikator keberhasilan kegiatan pengabdian kepada masyarakat ini bertumpu kepada;(1) kehadiran khalayak sasaran dalam setiap tahapan kegiatan,rata-rata (80\%);(2) jumlah khalayak sasaran yang menginginkan kembali kegiatan ini kembali dilaksanakan,sekitar(95\%); (3) pengetahuan dan keterampilan dalam membuat keputusan $(80 \%)$, pengetahuan umum kesehatan dan memanfaatkan limbah sawit $(85 \%)$.

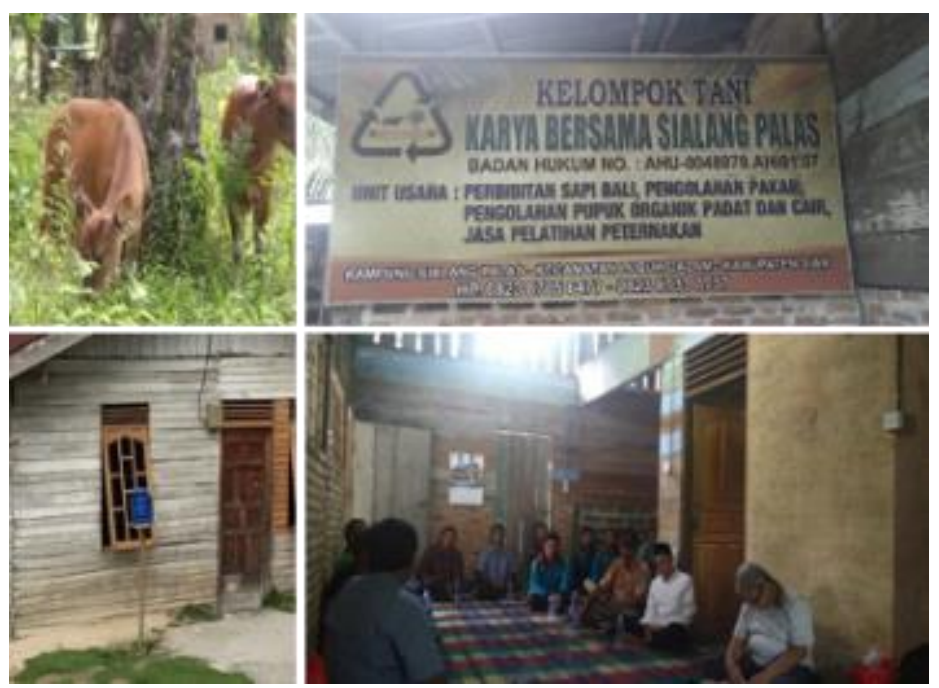

Gambar 3. Lokasi Kegiatan Pengabdian 


\section{KESIMPULAN}

Setelah kegiatan pengabdian kepada masyarakat ini dilaksanakan para pihak misalnya pemerintah kampung dan petani Poktan Gapoktan sebatas dapat tambahan pengetahuan dan keterampilan belum perubahan perilaku politik. Pengetahuan memahami relasi kuasa dalam memformulasikan keputusan dan kebijakan publik pembangunan. Selain itu para petani Gapoktan dan Poktan dapat mengelola potensi sumberdaya limbah sawit. Pengetahuan dan keterampilan ini didapat dengan ceramah dan diskusi daring dengan memanfaatkan penerapan model "politik pemberdayaan" dan aplikasi "sawitku". Dampak kegiatan pengabdian ini diharapkan dapat memberikan inspirasi bagi pemicu perekonomian dan kesehatan rumah tangga petani, tersosialisasikan sedemikian rupa dalam kehidupan masyarakat di Sialang Palas.

\section{UCAPAN TERIMA KASIH}

Kepada Lembaga Penelitian dan Pengabdian Kepada Masyarakat (LPPM) Universitas Riau yang telah mendanai Riset GB tahun 2020 dan Pengabdian Kepada masyarakat tahun 2019

\section{DAFTAR PUSTAKA}

Abrahamse, W., \& Steg, L. 2013. Social influence approaches to encourage resource conservation: A meta-analysis. Global Environmental Change, 23(6), 1773-1785. https://doi.org/10.1016/j.gloenvcha.2013.07.029

Anwar, K. 2019. The pattern of interaction of political actors on situations of tenurial conflict in watershed: Case of palm oil in Kampung Dosan. Journal of Science and Technology Policy Management, 10(5), 1098-1120. https://doi.org/10.1108/JSTPM-02-2018-0014

Anwar, K. 2019. Pemberdayaan masyarakat melalui penataan dan pembinaan organisasi pkk dalam memanfaatkan limbah sawit di kampung sialang palas-siak, Riau. Unri Conference Series Community Engagement: Seminar Nasional Pemberdayaan Masyarakat, 1(1), 442-448. https://doi.org/10.31258/unricsce.1.442-448

Anwar, K. 2017. Politik pemberdayaan petani di desa rambah muda,riau. Jurnal Ilmu Pemerintahan, 2(2), 103-118.

Anwar, K. 2012. Formulasi Kebijakan K21 di Bidang Perkebunan Kelapa Sawit. JIANA: Jurnal Ilmu Administrasi Negara, 11(2), 125-137.

Badan Pusat Statistik. 2010. BPS dan Bappeda Provinsi Riau dalam Angka. Indonesia (ID): Badan Pusat Statistik Pekanbaru

Casson, A. 2000. The hesitant boom: Indonesia's oil palm sub sector in an era of economic crisis and political change. Occasional Paper, 29(1), 1-49.

Cherayi, S., \& Jose, J. P. 2016. Empowerment and social inclusion of Muslim women: Towards a new conceptual model. Journal of Rural Studies, 45, 243-251. https://doi.org/10.1016/j.jrurstud.2016.04.003

Frieden, Jeffry (etl). 2000. The method of analysis: modern political economy. Modern Political Economy Theory and Latin and America Policy, 37-43. Princeton (NJ): Princeton University Press

Jaringan Kerja Penyelamat Hutan Riau. 2016. Jeda Tebang Hutan Di Wilayah Provinsi Riau. Indonesia (ID): Jaringan Kerja Penyelamat Hutan Riau. http://jikalahari.or.id/wpcontent/uploads/2016/03/KERTASPOSISI

Mas'oed, M. 2005. Negara, Kapital, Dan Demokrasi. Indonesia (ID): Pustaka Belajar. ISBN 9798581113

Hicks, C. C., Graham, N. A. J., \& Cinner, J. E. 2013. Synergies and tradeoffs in how managers, scientists, and fishers value coral reef ecosystem services. Global Environmental Change, 23(6), 1444-1453. https://doi.org/10.1016/j.gloenvcha.2013.07.028

O'Hara, C., \& Clement, F. 2018. Power as agency: A critical reflection on the measurement of women's empowerment in the development sector. World Development, 106, 111-123. https://doi.org/10.1016/j.worlddev.2018.02.002

Rai, P., \& Smucker, T. A. 2016. Empowering through entitlement? The micro-politics of food access in rural Maharashtra, India. Journal of Rural Studies, 45, 260-269. https://doi.org/10.1016/j.jrurstud.2016.04.002

Sumarti, T., Rokhani, \& Falatehan, S. F. 2017. Strategi pemberdayaan petani muda kopi wirausaha di kabupaten simalungun. Jurnal Penyuluhan, 13(1), 31-49. https://doi.org/10.25015/penyuluhan.v13i1.15165

Syahza, A., Rosnita, Suwondo, Nasrus, B. 2013. Potential oil palm industry development in riau. International Research Journal of Business Studies, 6(2), 133-147. 